\title{
THE ANALYSIS OF SERVICES QUALITY EDUCATION BY TEACHER'S PROFESSION IN THE MINIMUM OF SERVICE STANDARDS
}

\author{
Nurismilida \\ Surel: nurismilida@gmail.com
}

\begin{abstract}
This article will discuss the importance of quality education services and their implementation in education with the teacher as the executing subject. Service quality of education itself has a specific standard as the reference for the implementation of educational services that must be obey, this standard issued by the Ministry of Education in National Education Minister Regulation No. 15 in 2010 entitle with The Minimum Of Service Standards. This research was conducted by sending an email containing a questionnaire to some teachers at SMK 2 Langsa and MTS Galih Agung Lau Bakery in March 2016. The population is all teachers in the school and a sample of eight people. Based on the research results, the authors conclude that the condition of teachers in these schools understand enough about quality education services but do not know on Minimum Service Standards.
\end{abstract}

Keywords: Minimum Service Standards, Quality of educational services

\section{INTRODUCTION}

According to Philip B. Crosby, quality is in conformity with what would otherwise require. According to Edwards Deming, the quality is conformance to requirements. So it can be concluded that the quality is some aspects that required or needed. Quality of education services is the quality of service that will be or have been carried out in nature an educational institution with certain conditions for realizing a need in the education itself. Regarding the times are growing and competitiveness is so high that it is fitting for any professional services should be upgraded, especially in education.

Definition of education according to law No. 20 of 2003 on
National Education System or the National Education, Article 1 (paragraphs 1 and 4), education is a conscious and deliberate effort to create an atmosphere of learning and the learning process so that learners are actively developing the potential for him to have the spiritual strength of religious, noble character, selfcontrol, intelligence, personality, and the skills required for himself, society, nation and the country. Education is a major factor in the formation of the human person. Education was instrumental in forming the human person is good or bad according to the normative size. Therefore educators should provide quality services in education.

In fact, educational services quality in Indonesia does not 
including overall quality. Often SPM (Standar Pelayanan Minimal) is not executed even some teachers who do not know what it is SPM. To four qualities in education that is input, process, output, and outcome are also often less appropriate application, which means less quality. This is due to lack of awareness of a teacher or educator within the profession.

Solutions that can be done by these educators is to always strive to realize the importance of professionalism themselves by following the activities that can improve the quality of service in education such as attending professional organizations, educational seminars, research, and so forth. A teacher must also meet the standards of competence, namely; have expertise that is specific, minimum education level (for a teacher) and certification expertise. Teachers also have to master the skill in the ability of the material and methodology skills.

\section{RESEARCH METHODS}

In this article the author uses qualitative descriptive method, which is a research procedure that uses descriptive data in the form of words written or oral that can be observed on the subject itself. Research will present level of understanding and ability of teachers to improve the quality of service as an educator.

The time of this study coincide on Tuesday on March 17, 2016 via email using the techniques of data collection questionnaire (Questionnaire). The study was conducted on teachers N 2 Langsa many as four people and private junior high school teacher Galina Supreme Lau Bakeri, Deli Serdang as many as four people anyway.

By using quota sampling technique that is performed on the basis of the subject is a person who easily found so as to facilitate the data collection process.

\section{DISCUSSION}

\begin{tabular}{|c|l|l|l|l|l|}
\hline No & \multicolumn{1}{|c|}{ Question } & A & B & C & D \\
\hline 1. & $\begin{array}{l}\text { What do you think a } \\
\text { teacher should be done to } \\
\text { improve the quality of care } \\
\text { profession? }\end{array}$ & $100 \%$ & & & \\
\hline 2. & $\begin{array}{l}\text { Is there a connection with } \\
\text { the service quality of a } \\
\text { teacher wage / salary } \\
\text { received? }\end{array}$ & $50 \%$ & $25 \%$ & $25 \%$ \\
\hline 3. & $\begin{array}{l}\text { How do you think the } \\
\text { standardization of services }\end{array}$ & & $25 \%$ & $50 \%$ & $25 \%$ \\
\hline
\end{tabular}




\begin{tabular}{|c|l|l|l|l|l|}
\hline of qualified teachers? & & & & \\
\hline 4. & $\begin{array}{l}\text { How the quality } \\
\text { improvement can be } \\
\text { realized in Indonesia? }\end{array}$ & $50 \%$ & $25 \%$ & $25 \%$ \\
\hline 5. & $\begin{array}{l}\text { Do you think that as a } \\
\text { teacher you've done quality } \\
\text { services? }\end{array}$ & $75 \%$ & $25 \%$ & \\
\hline
\end{tabular}

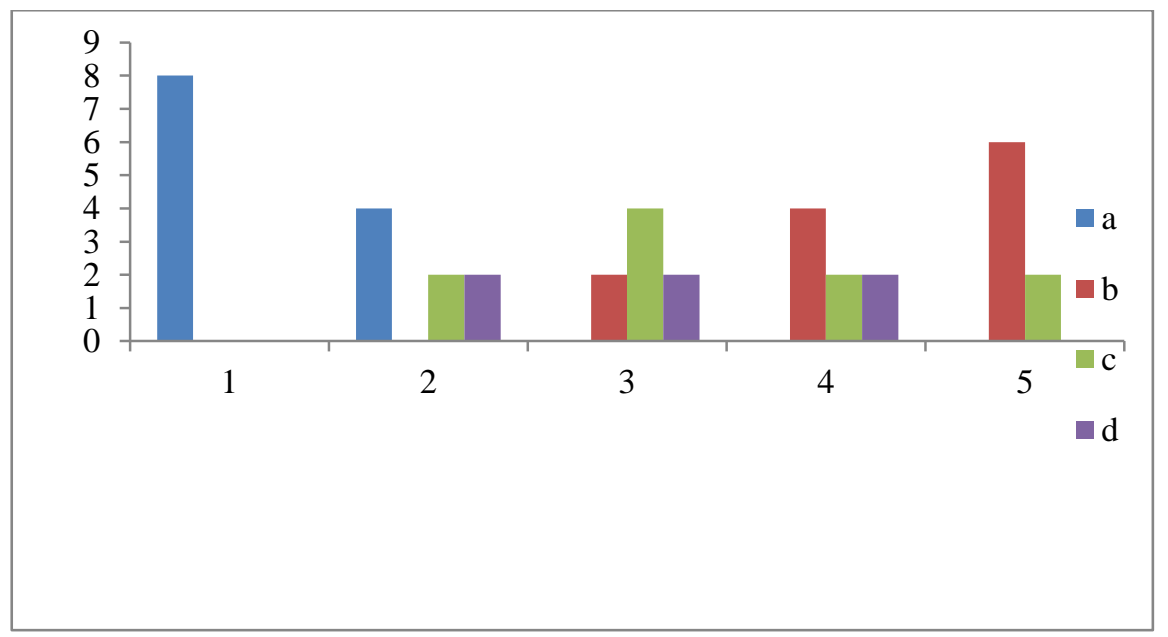

From the results above can be explained that the code of ethics of teachers was instrumental in improving service profession, as evidenced by the approval of all teachers were given a questionnaire to this. Then, most of the teachers found to do the quality of service provided to the teacher salary he received. Most teachers also argued that the standardization of services that qualified teachers must always strive to establish good cooperation between the school communities. And no one who chooses Minimum Service Standards set by the government as the answer. Items that are associated with an increased quality of professional services to be realized in Indonesia according to the majority of teachers are also heavily influenced by a close relationship with the world profession. Lastly, there are no teachers who said they would have to provide services quality in education, there is only the word "yes" and "maybe." This shows the teacher doubts on the quality of service that has been done in education.

In the quality of education services, it appears that Indonesia has its own requirements, called the Minimum Service Standard (SPM) which serves as a minimum standard that must be met by teachers. However, in reality through research conducted many teachers who do not know this standard, so that the teachers certainly can't meet the SPM 
as best as possible. In fact, the standard is very important as a reference for teachers in order to make his services in education better quality In this case the Minimum Service Standards for Basic Education, set forth in the Regulation of the Minister of National Education No. 15 Year 2010. Basic Service Standard is applicable to SD / MI and SMP / MT, while the Ministry of National Education of high school would still make at a minimum service standards.

\section{CONCLUSION}

The results showed that there are many teachers who do not know about the Minimum Service Standards, whereas SPM is an indication of the principal that must be met in the ministry of education. A teacher should further improve the quality of service in the quality of education based SPM applicable. Most said that for the implementation of quality education services teacher must Obey and adhere to the Code Guru, also get rewarded accordingly also has a close link between an educator by profession world.

Thus the teachers can return to the nature of their professional development during the tenure by following various seminars, refresher, workshops, trainings, workshops or other scientific activities in education, or also by electronic media and print media which can help teachers to improve professionalism in education services.

\section{REFERENCES}

Disdikpora. 2011. Standar Pelayanan Minimal Untuk SMA/SMK Akan Dibuat. http://disdikporaboyolali.info/news/694/standa r-pelayanan-minimal-untuksma-smk-akan-dibuat.aspx. (Diakses pada tanggal 20 Maret 2016).

Kalimanjaro, Noldy. 2011. Profession al Guru dalam Peningkatan Mutu Kependidikan. http://www.slideshare.net/nol dykalimanjaro/ profesionalguru-dalam-peningkatanmutu-kependidikan. (Diakses pada tanggal 20 Maret 2016).

Media Pusat. 2013. Pengertian Mutu Menurut Para Ahli. http://www.mediapusat.com/2 013/12/pengertian-mutumenurut-para-ahli-dan.html. (Diakses pada tanggal 20 Maret 2016).

Surat Pendidikan. 2013. Pengertian Mutu Pendidikan. http://seputarpendidikan003.bl ogspot.com/2013/06/pengertia n-mutu-pendidikan.html.

(Diakses pada tanggal 20 Maret 2016). 